\title{
BEHAVIOUR FEATURES OF THE PERSIAN LEOPARD (PANTHERA PARDUS SAXICOLOR) DURING DIFFERENT STAGES OF THE ESTROUS CYCLE
}

\author{
Makhar M. Ertuev, Umar A. Semenov \\ Sochi National Park, Russia \\ e-mail:mr.ertuev38@gmail.com,umar-semenov@rambler.ru
}

Received: 12.09 .2016

\begin{abstract}
The implementation of the programme for the reintroduction of the Persian leopard in the Caucasus in Russia allowed carrying out a detailed video monitoring of various aspects of this subspecies' life under captive conditions in the «Center of the leopard recovery in the Caucasus». The most important stage of this programme was the formation of couples and the progeny getting of adult individuals caught in their natural environment and placed into a closed aviary. A complex sexual behaviour of leopards, while having different stages of the estrous cycle, could be identified by manifestation of characteristic features in various stages. There is an increase in both the motion behaviour as well as in the marking activity during proestrus; the cozying that helps to maintain the sexual activity of the male and the adopting of the receptive pose of the female during the estrus; avoidance of mating by the female during the proestrus stage; transition of the mating initiative to the male as well as passive behaviour of the female during the metaestrus stage. A large number of matings is caused by the species' biology. The leopard belongs to the animals with an «instigated» ovulation. Therefore the multiple coituses stimulate the maintaining of a high concentration of estrogens in the blood and promote the ovulation of follicles. As a result, we have concluded that the form of female sexual behaviour (with permissible error) can indicate the functional activity of the ovaries and the corpora lutea, as well as it allows determining the beginning and duration of the stages of the estrous cycle.
\end{abstract}

Key words: coitus, estrus, mating, Panthera pardus saxicolor, Persian leopard, sexual behaviour.

\section{Introduction}

The level and ratio of hormones have a considerable influence on the behavioural responses of animals. However, this influence could be mediated through the central nervous system (CNS). Due to this fact, in recent years the interest in the problem of the influence of sex hormones on neurons and neuroglia of the brain has grown. According to Vunder (1973), Rozen (1984), Babichev (2013) the increased secretion of estrogens in animals precedes to the onset of estrus. Under the influence of estrogen, there occur eroticisation of the brain, awakening and exacerbation of the sexual instinct, as well as the co-ordination of the female sexual behaviour and the increasing of her receptive components. Some authors (Etgen, 2003; Babichev, 2013) demonstrate that sex steroids influence the behaviour of animals. These affect on many of the specific brain structures as within the hypothalamic-pituitary-gonadal system (HPGS) as well as outside it.

According to the results of many researchers (Etgen, 2003; Tang et al., 2004; Toran-Allerand, 2005; Tetel, 2009; Hussainet al., 2011; Kelli \& Mermelstein, 2011; Babichev, 2013), sex steroids are not only able to penetrate through the blood-brain barrier, but also to influence the brain structures, lying outside the hypothalamic region (hippocampus, neocortex, the forebrain region, substantia nigra, etc.).
Consequently, behavioural reactions are modulated in these structures; processes like the secretion of sex hormones and an increase of their concentration in the brain tissues, activation of estrogen and progesterone receptors occur. Therefore, affecting the neurons of the brain, sex steroids control the secretion of gonadoliberines by the hypothalamus and follicle-stimulating hormone (FSH) and luteinizing hormone (LH) by the pituitary.

The cyclicity of female sexual processes causes the wave nature of the growth and maturation of follicles and corpora lutea secreting estrogens and progesterone. The latter are able to change rhythmically the functional activity of both the hypothalamus and pituitary gland, and as a result, the concentration of LH and FSH in the blood. The cyclic LH emission causes the rupture of the follicle and ovulation. In this regard it should be noted that in some animals (including the leopard) the cyclic hormone emission and ovulation are the reflex processes on the act of mating. So, for example, it needs at least 19 matings to start the ovulation of the shrewmouse (Lomteva, 2008). Cyclical changes in the level of estrogen and progesterone caused by the rhythmic change of the follicular and luteal phases in the ovary are manifested in the form of the estrous cycles. The aim of this paper is to study the sexual behaviour of the Persian leopard in the different periods of the estrous cycle. 


\section{Material and Methods}

Observations have been carried out in the «Center of the leopard recovery in the Caucasus» located in the $67^{\text {th }}$ forest compartment of the Adler forest division in the Sochi National Park (Russia). The Center covers a total area of $0.12 \mathrm{~km}^{2}$ and consists of functional sectors with aviaries. The Center is located in typical habitats of the historic range of the Persian leopard at an altitude of $600 \mathrm{~m}$ above sea level on the terraces of wooded slopes.

Until the 19th century, the leopard was fairly widespread in the Caucasus and occupied almost all mountain areas. However, the constant hounding and targeted extermination of the leopard as well as of its animals of prey had led to the fact that by the mid-20th century, it has practically ceased to reside permanently in the North Caucasus.

Within the framework of scientific support for the programme of the reintroduction of the leopard in the Caucasus, the genetic analysis of individuals was conducted. The latter has determined the taxonomic status of the subspecies historically inhabited this area. Also, the results of the genetic analysis allow using individuals in programmes with animals from zoos and those living in other countries but belonging to the same subspecies. Carried out researches revealed that the leopard which inhabits the south of Central and Southwest Asia (including the Caucasus), is larger than leopards from other locations of the range, and it belongs to the same leopard subspecies. In Russia, it was described as Panthera pardus ciscaucasicus Satunin, 1914 - Persian leopard. And in 2001, it was included in the Red Data Book of the Russian Federation with the rarity category 1 (Endangered species). However, the name Panthera pardus saxicolor Pocock, 1927 got more widespread in the world. But, as researchers have correctly noted, the problem of the taxonomic and nomenclatural status of the leopard in the entire Caucasus region requires clarification (Rozhnov et al., 2007).

At present, this subspecies has survived only in inaccessible areas of the Eastern Caucasus. These groups, insignificant by size, with broken structure, are underpinned by the migration of individual animals, including those from Northern Iran. Because the self-recovering of the Caucasian population under the current conditions proves to be impossible, a special programme for the recovery (reintroduction) of a leopard population in the Caucasus has been developed (Rozhnov \& Lukarevskiy, 2006). The crucial stage in the implementation of the programme has become the equipping of the special centre where couples will be formed to get progeny and then prepare them for an independent life in their natural environment.
The study of the behavioural responses during different stages of the estrous cycle was performed on animals that have been removed from their natural habitats in mountain regions of Turkmenistan and Iran. Therefore, these animals were adapted in conditions of aviary detention in the Western Caucasus. The study of the behaviour of these animals is of great scientific and practical significance. In captivity they are more susceptible to the effects of stress factors. This is a long-term anthropogenic influence and limitation of living environment, and as a consequence, hypodynamy. Each of these factors can activate the hypothalamic-pituitary-adrenocortical system (HPACS) and contribute to the increase of glucocorticoids in the blood of the animals. It is known that high concentrations of these hormones suppress the sexual function of animals (Meerson \& Pshennikova, 1988; Reznikov, 2007; Lomteva, 2008).

The individual behaviour of animals was studied in enclosures with an area of 345-412 $\mathrm{m}^{2}$ (Fig. 1). Fences of the aviaries of a height of 6 meters were constructed of coarse net stretched over metal poles. These fences have a concrete fundament. Metal profiles of a height of $2.5 \mathrm{~m}$ were welded on the upper part of the fences from its inner side to prevent the escape of animals. The infrastructure of each aviary includes the following elements: wooden 3D-construction; two-section wooden camera-lair with embedded video monitoring system in day/night mode; infrared spotlights and high-speed dome IP-cameras for the video monitoring in the aviaries in the day/ night mode; stony grotto-hideaway; drinking bowl; retractable metal feedbox; cylindrical metal feedbox; artificial hole to launch the animals for feeding; wooden cylinders; wooden balls with «odour» holes; boxes with various soils and materials of filling; natural wood, shrub and herbaceous vegetation; vane dampers remote-controlled to move animals.

During the investigations, the diet of the predators consisted of meat on the bone (beef) and live feed (quail, nutria, rabbit). Depending on the condition of the animals, they were hungry 1-2 days a week.

To study the animal behaviour throughout the day, the surveillance cameras «Axis» and the IR illuminators «Axis» were used. The equipment allows zooming in so close that separate hairs on the animal body can be seen. The software TRASSIR includes the function of archiving of any time periods and it allows viewing them subsequently at different speeds.

The observations have carried out by continuous logging. We have noted nicknames for certain animals, the weather, date and time of observation and behaviour types. Consequently, these results have helped to distinguish research, playing, marking and sexual behaviour types. 


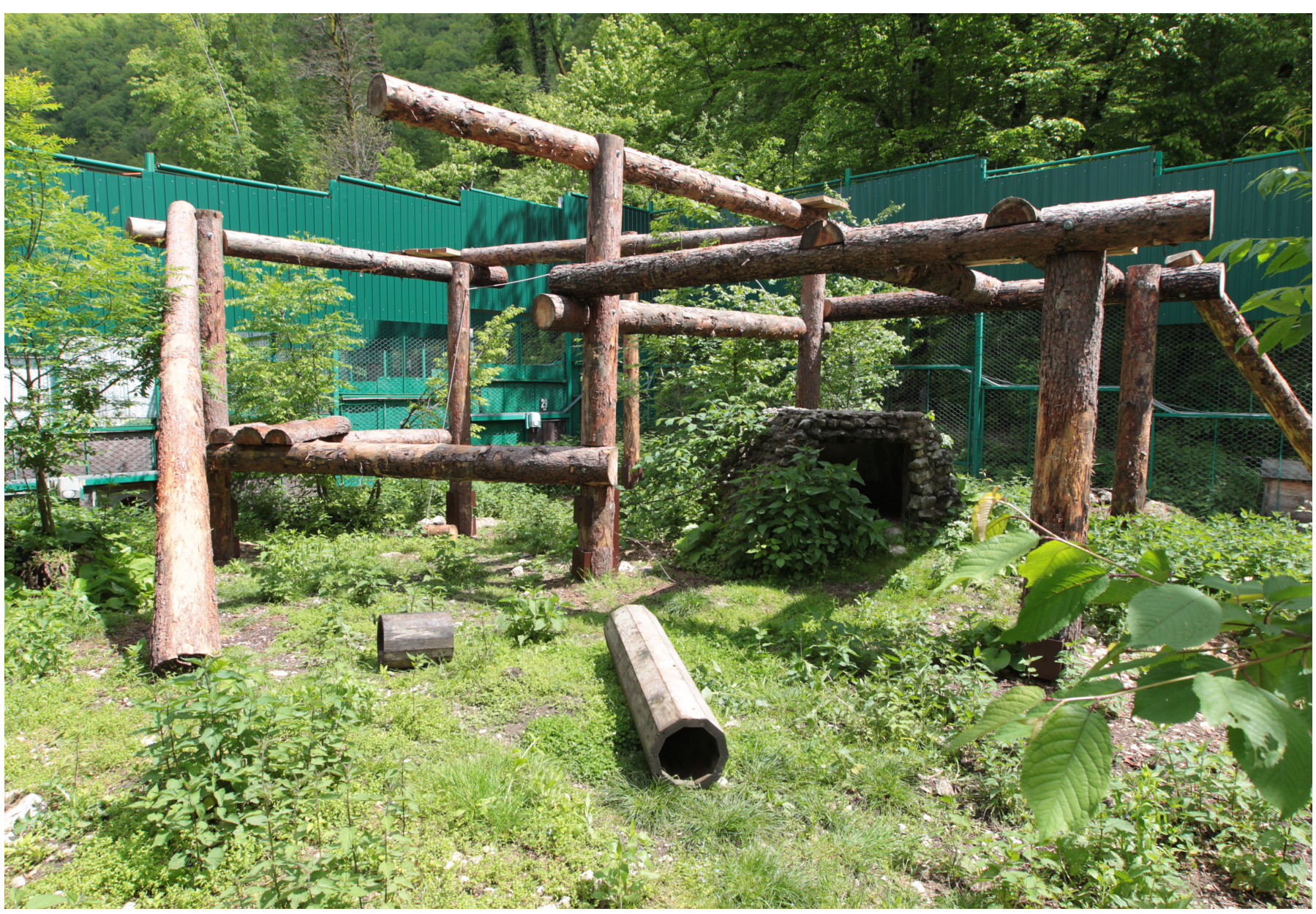

Fig. 1. Aviary for breeding № 5 in the Centre of the leopard recovery in the Caucasus.

Investigations of the dynamics of the animal behaviour during the year have been carried out daily during daylight hours, either around the clock during periods of sexual behaviour activation. Assessment of animal motion activity has been carried out by the computational method. Of all the conditions in an aviary the assessment of motion activity is rather important, because hypodynamy (as a strong stress-factor) because of the limited environment strongly influences the behaviour of the leopard, a very movable animal.

When studying the animal behaviour it must be considered that the response to any new and sufficiently strong influence either from internal or from external environment is ensured by the system that reacts specifically to the irritant. At a certain stage of individual life, in response to the stimulus, the body forms a functional dominant system. It serves to implement the main task at this life stage through the subordination of the executive bodies and co-ordinates the functions of the nervous, endocrine, enzymatic and muscular systems (Ukhtomskiy, 1966). The increase of the functional activity of HPGS under the influence of external factors (e.g. season of the year, daylight duration) can serve as a trigger factor to the formation of the sexual dominant.
The level and the ratio of hormones play a significant role in the seasonal changes of the animal behaviour. These parameters are associated with the seasonal cycle of the functional activity of the hypothalamus, which (being a kind of collector of information from the environment) transforms incoming signals in hypothalamic signals (corticotropin releasing hormones). For example, under the day-length increasing the hypothalamus enhances the secretion of the corticotropin releasing hormones LH and FSH. As a result, the gonadotropic hormones released into the blood and promoted the secretion of sex steroids. However, it should be noted that the influence of the sex hormones on the regulation of the reproductive system as well as the modulation of sexual behaviour is mediated through the central nervous system (Vunder, 1973; Etgen, 2003; Babichev, 2013).

Usually, two methods are used when animal behaviour is studied in practice. The first method takes into account the functional activity of the endocrine glands on the basis of the concentration of hormones in the blood or other physiological functions of the body, which can be used to determine the possible behavioural reactions of animals. The other method takes into account the animal behaviour at various states of the neuroendocrine system. It allows to in- 
directly judging the functional activity of the endocrine glands, especially about the beginning and duration of the proestrus, the estrus and the metaestrus.

To conduct the more detailed analysis of the animal behavioural reaction during the rut, the estrous cycle was conditionally divided into three stages, depending on the type of their sexual behaviour: proestrus (from the date of change in the female behaviour, consisting of increasing of motional and marking activity, the permanent cozying and the stimulation of the sexual activity of the male, until the first mating); estrus (from the date of the first mating until either the passive avoidance of mating (female runs away into the lair or she lies in the rest position at the time of mating, stretching out both hind legs to one side) or the active avoidance of mating (female lies on her back and she fights back with her paws when the male is trying to mate); metaestrus (from the date of the beginning of mating avoidance by the female until the stop of the persecution by the male and the departure of the male into his own lair either into another aviary).

\section{Results and Discussion}

Long-term animal observation showed that all main behaviour types, characteristic for all the representatives of the cat family, are observed in the individual behaviour of the animals. We present data reflect motion activity, marking, playing and sexual behaviour, since they are more interconnected.

The results of the motion activity study showed a significant gender difference. So, the male Alous walks on the concrete base of one of the sides of the aviary (18 $\mathrm{m}$ in length), unlike other animals, who prefer to walk on a circle along the fence, either along the paths, trodden in the aviaries. By defining with a stopwatch the distance travelled per $5 \mathrm{~min}$. and, knowing the time spent on the walk, the desired length of the distance travelled can be calculated. The female Chery prefers to walk along the fence along the inner perimeter of the aviary. Then she walks along the paths, trodden by her in the aviary. The movement speed is determined knowing the length of the path along the perimeter of the aviary and the time spent to overcome this distance. The length of her way is calculated on the base of walking time and movement speed.

Thus, the average movement speed of the male was $5.7 \mathrm{~km} / \mathrm{h}$, of the female $4.3 \mathrm{~km} / \mathrm{h}$. The results of the observations showed that the average daily walking time of the male was 6.3 hours, of the female 2.4 hours. The daily distances travelled by Alous and Chery were 35.91 and $10.32 \mathrm{~km}$ respectively. Probably the large motion activity of males is associated with the fact that in the wild they spend more time on the circumvention of their territories, covering several areas of females. The results of the study of animal motion activity from September to January showed that no significant changes in this behaviour took place over this period neither in males nor in females.

The female behaviour changed two days before the beginning of the estrus. In particular, motion activity and its duration had increased, the marking behaviour had intensified. During these days the duration of her walking along the aviary had increased by 2.8 hours compared with the autumnwinter period. In this period the female made sharp movements, purposeless runs, constantly changing motion direction, it was difficult to determine the movement speed of the female, and therefore the distance she travelled.

Assessment and analysis of the sexual behaviour of the female during the rut allowed determining the beginning and the end of the various stages of the estrous cycle with a permissible error. Thus, the total duration of the estrous cycle was 167 hours and $40 \mathrm{~min}$. Of these, the duration of proestrus, estrus and metaestrus were 35 hours and 40 minutes, 78 , and 54 hours respectively.

On the first day of the estrous cycle (stage proestrus) the female behaviour changed. She made sharp displacements and purposeless runs along the aviary, swayed the car tire hanging on the tower, quickly and unexpectedly ran on the crossbar of the vane damper and on the tower, and then jumped down. She made an odour mark in the corner of the aviary. The female constantly pursued the male, concealing and attacking him. The behaviour typical for the proestrus stage more clearly manifested itself after 18 p.m., when the content of estrogen in the blood increased significantly. The female began to somersault sideways, rubbing her cheekbones and neck both against the ground and the metal pole of the tower. She unexpectedly jumped up and again made purposeless runs, somersaulted and rubbed cheekbones and neck against the ground, while the female's tail was continuously raised up or taken aside. She often rubbed by sacral and pelvic parts of the body against the metal poles of the tower, mesh fencing, shrub (Fig. 2), flirted with the male and stimulated his activity (Fig. 3), but she did not permit him to mate, lying on the back and fighting off with her legs.

The analyses showed that the highest frequency of the summersault $(60.8 \%)$ was observed on the first day of the estrous cycle. This coincided with the beginning of the proestrus stage (Fig. 4). 


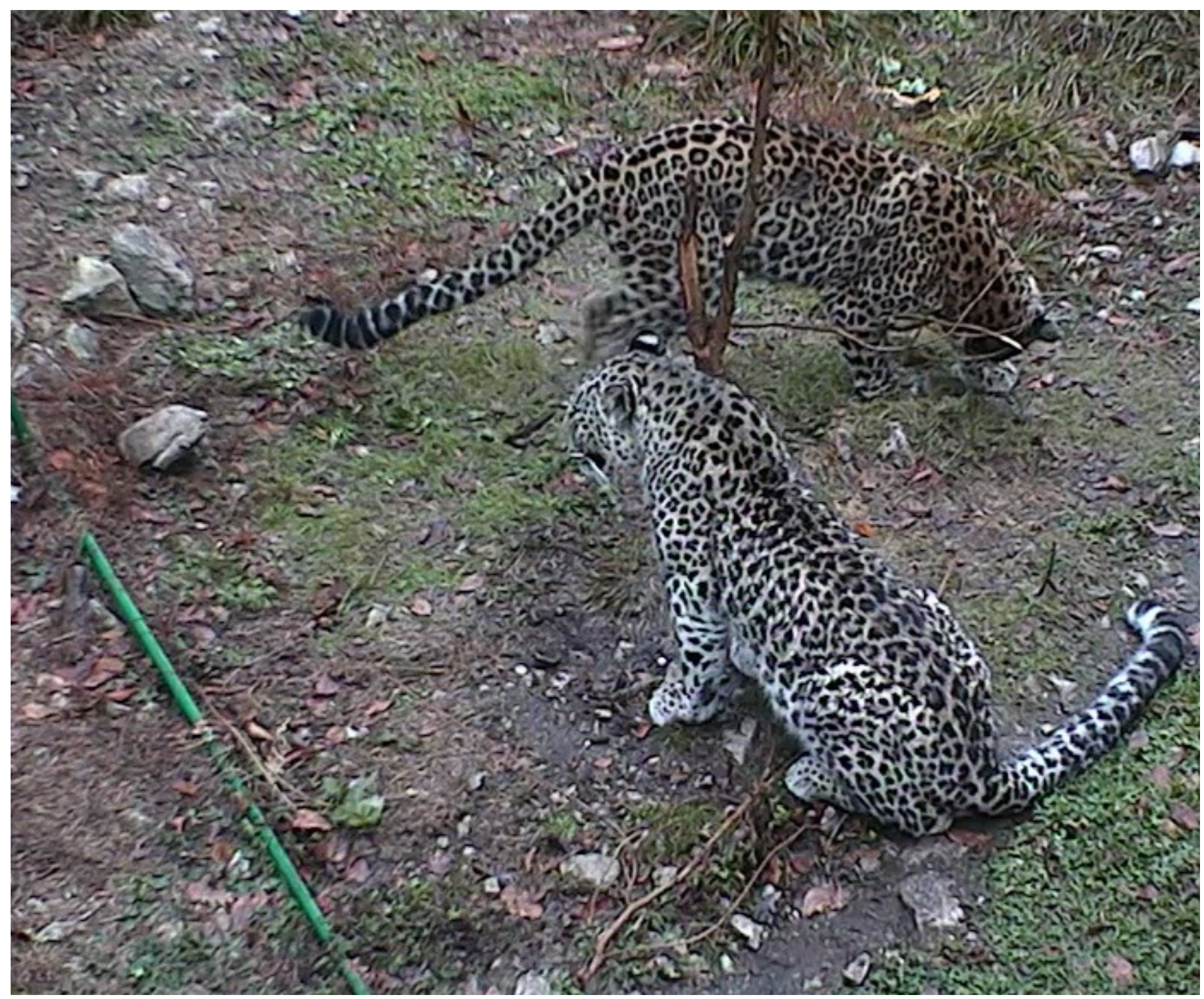

Fig. 2. The female rubs the back of her head against the branches of the bush.

This is probably related to an increased estrogen concentration in the blood of the animals. Above it was noted that the high level of sex steroids co-ordinates and integrates behavioural acts of animals by acting on various brain structures, both inside and outside the hypothalamic region. The frequency of the summersault was high on the second day $(21.7 \%)$ too. However, further there was a significant decrease of manifestation of this behaviour and complete cessation of its activities on the fourth day of the estrous cycle. This may indirectly indicate the significant decrease in the estrogen concentration in the blood. The frequency of proceptivity manifestation increased from $16.3 \%$ on the first day of the proestrus to $42.4 \%$ in the early stage of the estrus and remained on a high level on the third day $(18.2 \%)$ of the estrous cycle.

The intensity of marking behaviour (urination, rubbing her cheekbones and neck area against the tower poles, ground and entrance to the grotto) increased on the first day of the estrous cycle and amounted to $9.8 \%$. On the second and third day it was 21.6 and $27.4 \%$ respectively, which coincided with the estrus stage. During the metaestrus stage the marking behaviour (except urination) has stopped completely. Evidently, this is associated with an increase of the progesterone concentration and a decrease of the estrogen concentration in the animal's blood.

On the first day of the proestrus stage we observed an increase in the female's marking behaviour and, consequently, the spread of pheromones increased, as well as the female frequently wallowed sideways. At the same time the male began to make scrapes with his four paws and marked its territory. Then the male sniffed the sections of the aviary, where the female was lying, and came back in the aviary. Then, sniffed around urinary marks made by the female, the male continued to make scrapes and to mark the territory of the aviary. Only after the marking of the territory the male walked to the female and, sniffing her, began to pursue her and made attempts to mate. According to data of several researchers (Khusmatullina, 2009), the exclu- 


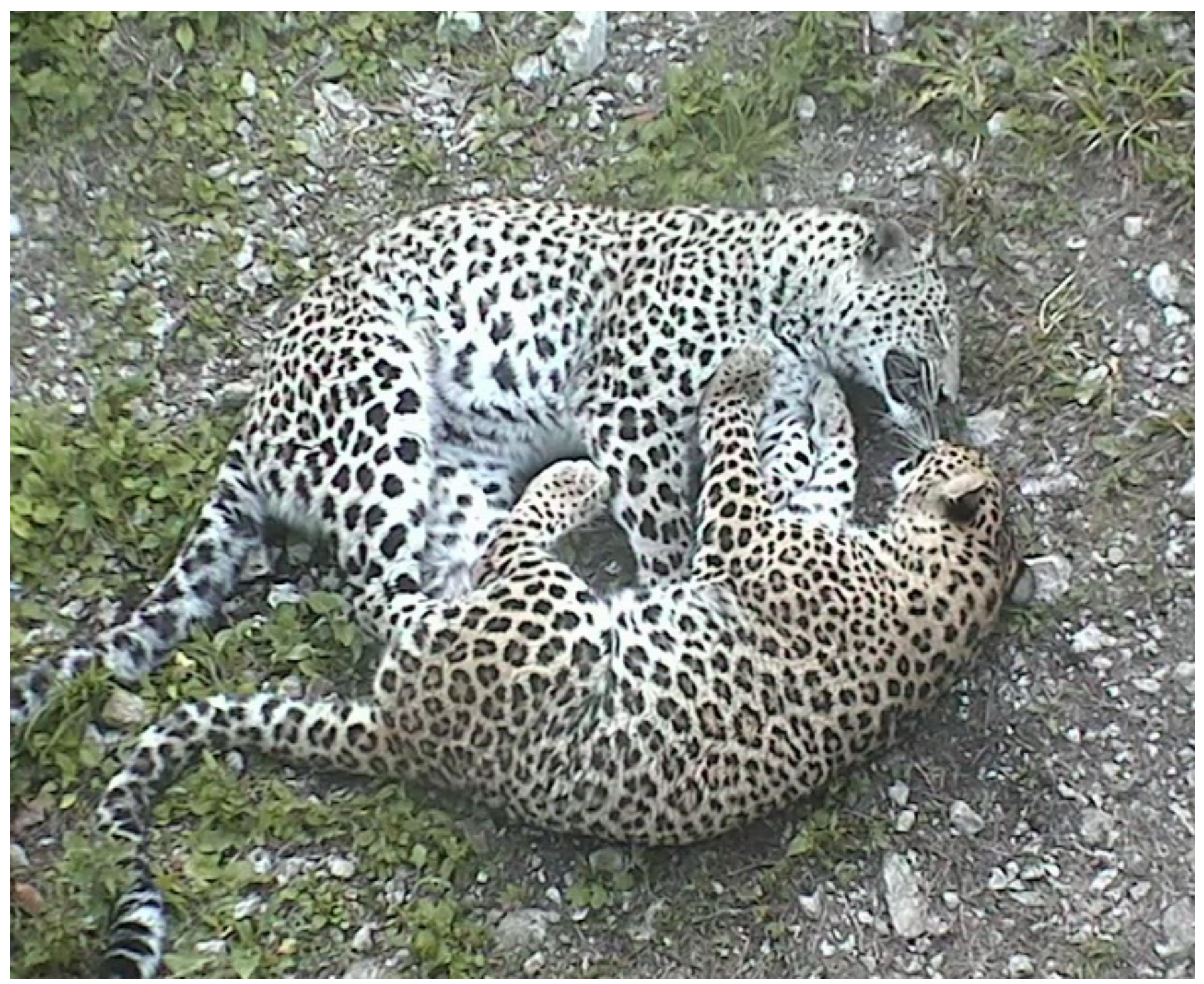

Fig. 3. The female flirts with the male.

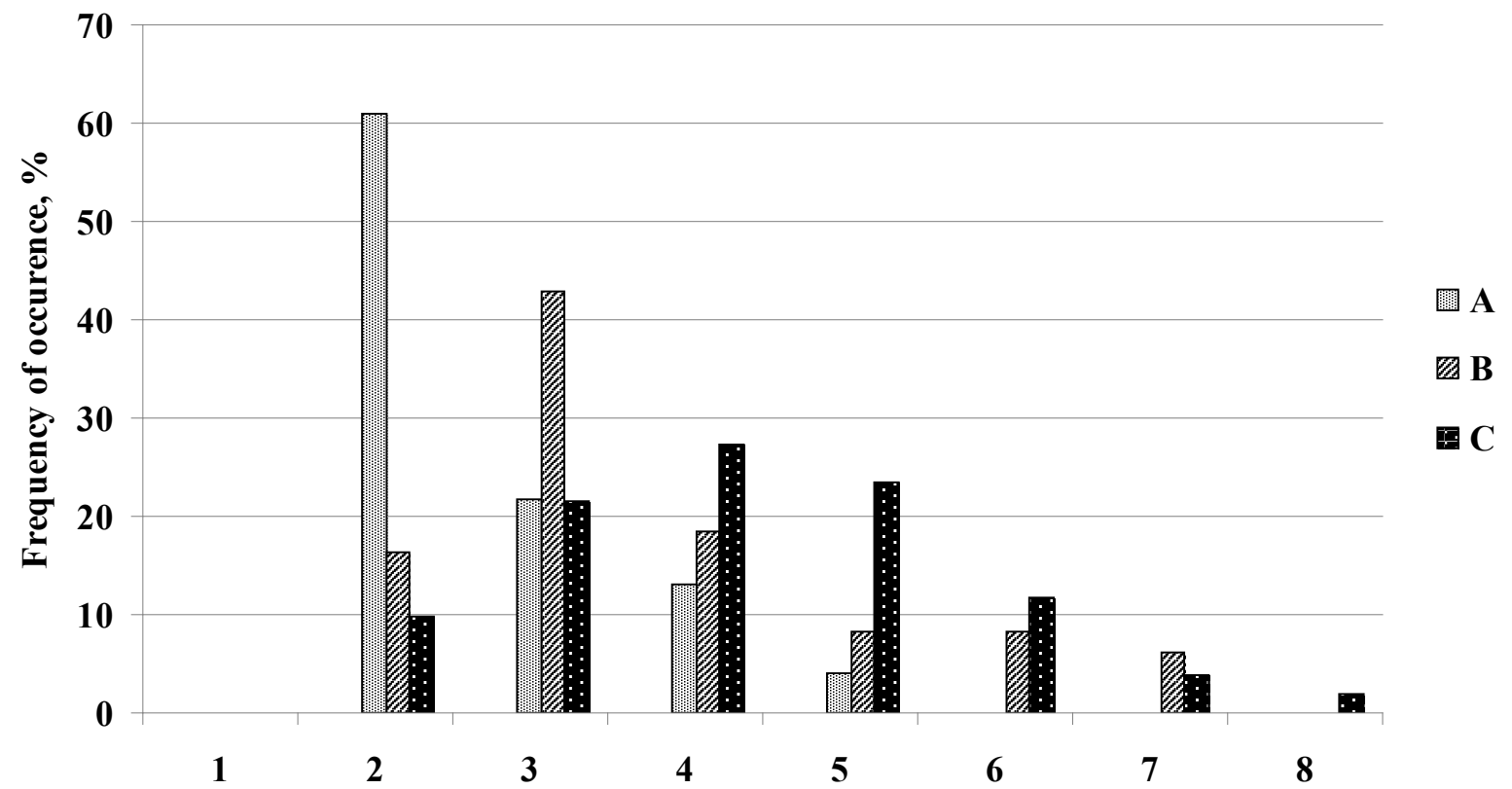

Estrous cycle, days

Fig. 4. The frequency manifestation of the female sexual behaviour in various stages of the estrous cycle (data for the whole period of the estrous cycle taken at 100\%). A - summersault, B - receptiveness components, $\mathrm{C}$ - marking behaviour. 
sive importance to increase the sexual activity of the male has olfactory incentives, analyses of which are carried out in the amygdaloid complex. But the female actively avoided the mating, lying down on her back and fighting back with her paws because the estrus stage of the female had not come yet. At the same time, with the weariness of the male from constant persecution and attempts to mate, the female attacked him, flirting, trying to stimulate his sexual activity. It is known that the female contact with the male, tactile sensations, received by her when attempting to mate, is contributed to the significant increase in the estrogen content in her blood. It is necessary for the onset of the estrus stage.

On the first day of the estrus stage, the frequency of the marking behaviour of the male was $33.3 \%$, and it was $25.0,8.3$, and $33.3 \%$ on the second, third and fourth day respectively. On the following days, the marking behaviour of the male corresponded to the basal level.

Courtship games have continued till the beginning of the estrus stage at 5:05 p.m. on the second day of the estrous cycle. After the next attack at the male the female went in another aviary, and then she came back and laid down $60-80 \mathrm{~cm}$ in front of the male, allowing him to mate. The first mating happened (Fig. 5).

At the same time the female took a receptive posture, made an oncoming search movement and raised her pelvis at the time of coitus, which is necessary for the ejaculation by the male (Fig. 6).

A severe irritation of the cervix and vagina occurs in case of a successful mating, and after the coitus the female lay down on her side and somersaulted in opposite directions. It should be noted that after the first mating, the male has no longer pursued the female. He lay down near the place of the first mating and only watched her moving along the aviary, waiting for her return. After 3 minutes, the female returned, again laid down $60-80 \mathrm{~cm}$ in front of the male and adopted a receptive posture. Upon receiving a severe irritation due to the next mating, the female lay down on her side and began to somersault sideways, tugging with her paws her own cheekbones and neck.

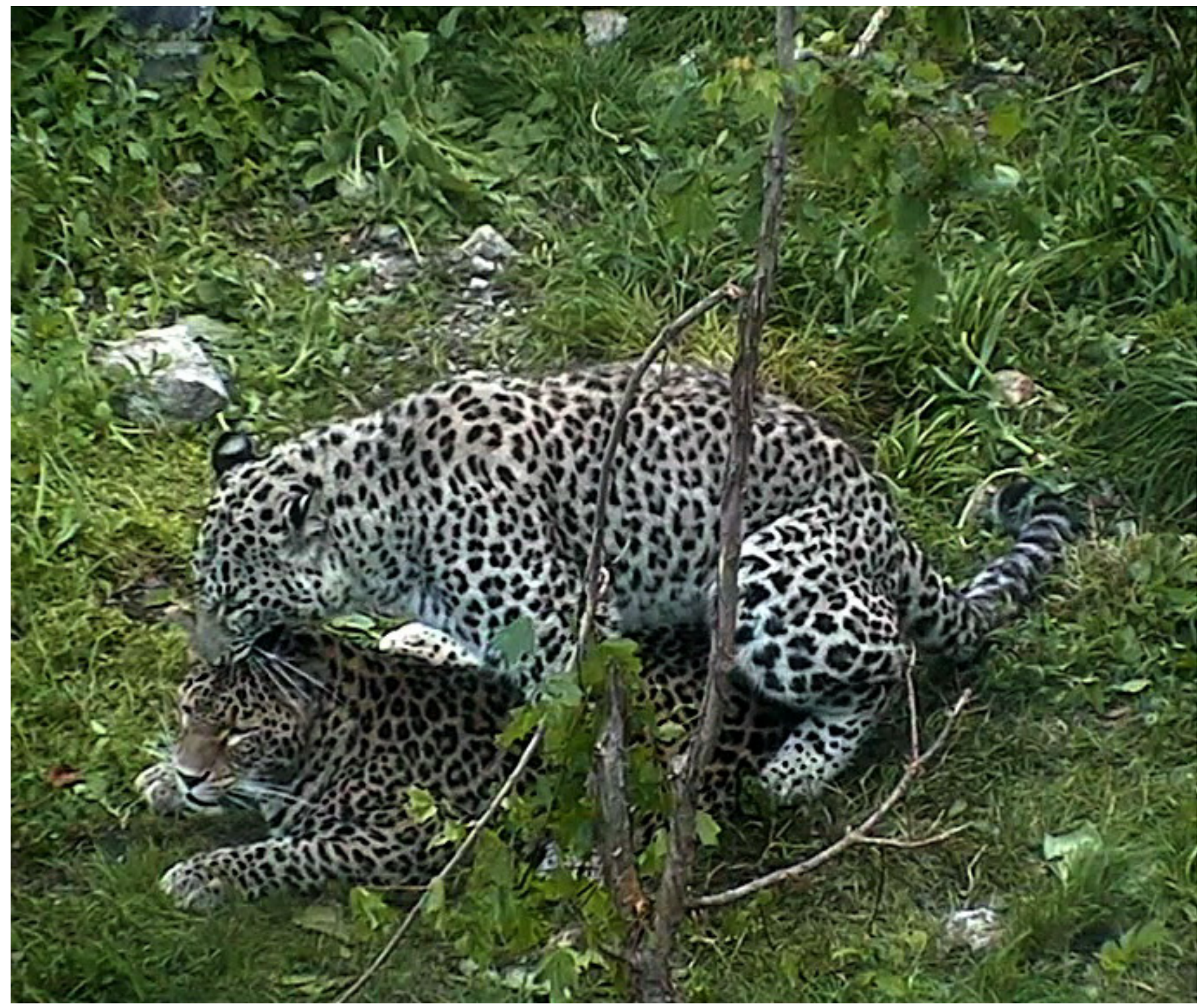

Fig. 5. The first coitus. 


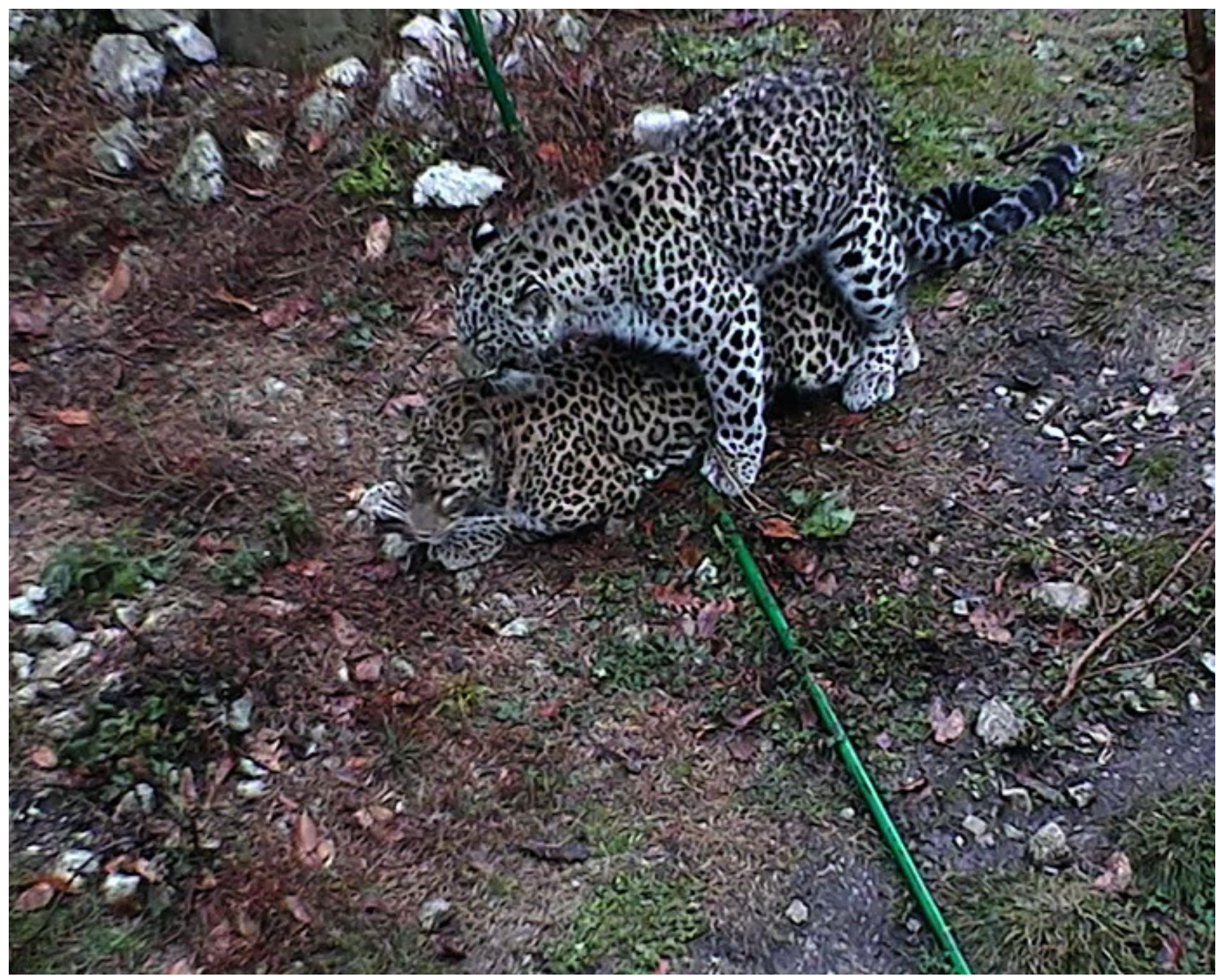

Fig. 6. The female takes a receptive posture and raises her pelvis.

The method of continuous logging allowed us to distinguish the following conclusions:

- Successful mating happens when the female takes a receptive posture, and she lifts the pelvis during coitus and makes an oncoming search movement, helping the male; she somersaults and rolls around on her side or the back after getting irritation during the coitus;

- Mating with questionable effectiveness (mating without intromission) is characterised by the lack of the behaviour observed in case of successful mating;

- The attempt to mate: when the male tries to mate the female actively avoids mating, laying down on her back and fights back with her paws. Either under the male pressure she obediently lies down, stretching her two hind legs to one side; with such posture the male tries to cover her, but it is always without results. Fig. 2 shows the manifestation frequency of sexual behaviour forms at different stages of the estrous cycle.

During the proestrus stage the female actively avoided mating during 35 hours and 40 minutes from the beginning of the estrous cycle; we did not observe any successful mating or mating without intromis- sion. However, 36 successful matings (that represents $23.5 \%$ of their total number) were registered on the second day, with the beginning of the estrus stage. The highest frequency of successful mating was observed on the third (31.4\%) and fourth $(32.7 \%)$ day of the estrous cycle. Later, a significant decline in animal sexual activity was observed. This may be indirect evidence of the gradual completion of the estrus phase and the beginning of the metaestrus stage.

The dynamics of mating without intromission has an entirely different character. Five unsuccessful attempts of mating $(6.2 \%)$ were observed on the second day of the estrous cycle. However, on the following days, the frequency of such mating increased significantly and it amounted to $38.7 \%$ on the fifth day of the estrous cycle. This is probably caused by «sexual saturation», weariness of the male, as well as by active and passive avoidance of mating by the female. The female does not «substitute herself»" any longer and does not take a receptive posture. Because of this the number of successful attempts of mating decreases and the number with questionable effectiveness increases. 


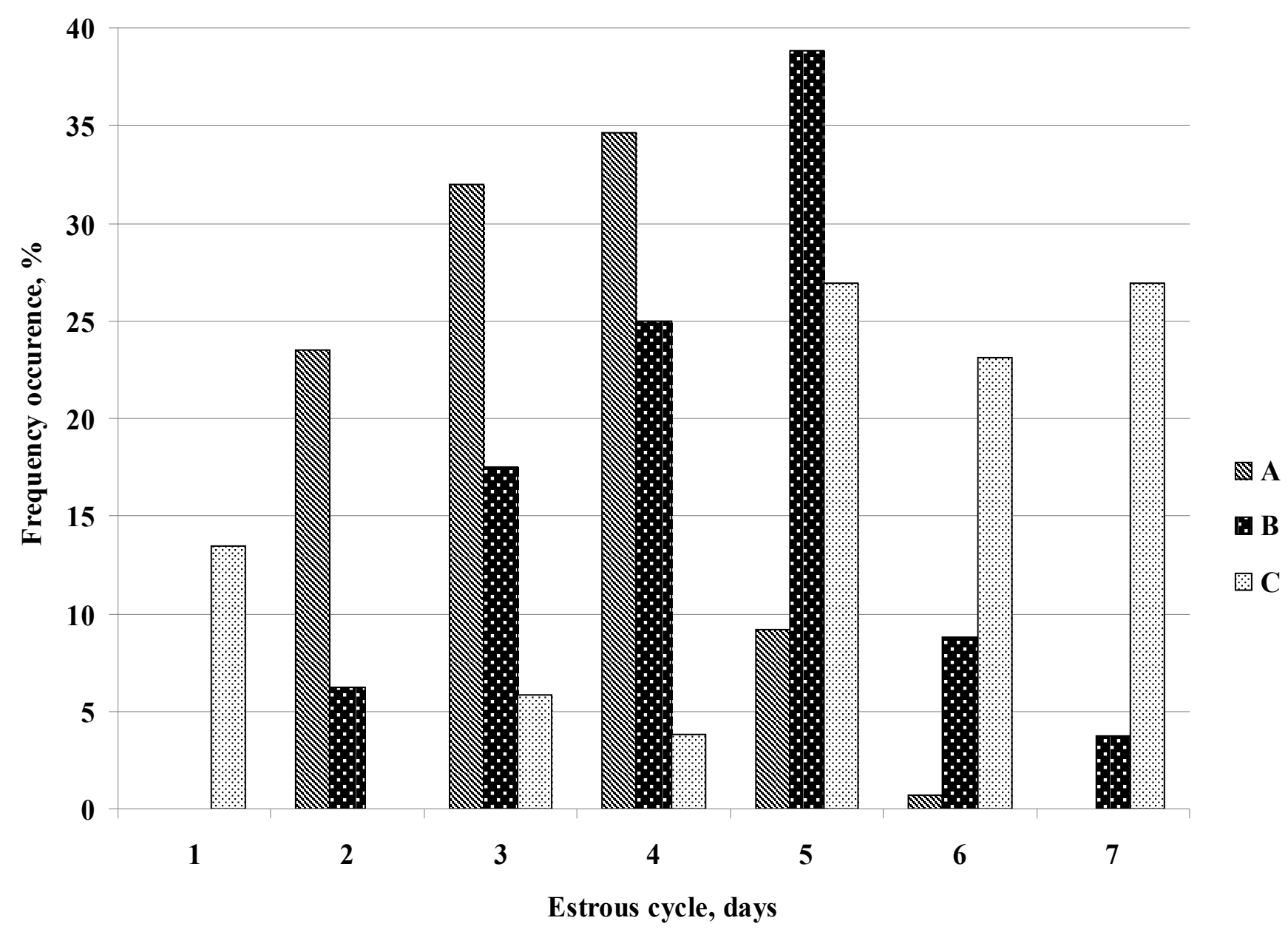

Fig. 7. The frequency of manifestation of various behaviours of the female at different stages of the estrous cycle (A - successful mating, $\mathrm{B}$ - mating without intromission, $\mathrm{C}$ - attempt to mate).

The last days of the estrous cycle, the female avoided mating passively, hiding in her lair, or taking a rest posture during a mating attempt. Furthermore, it should be noted that changes in the progesterone and estrogen ratio in the blood in favour of the estrogen to the end of the estrous cycle, appear to promote the regression of the process of brain erotisation by sex steroids.

During the proestrus stage, when the female did not allow the male to mate, the frequency of attempts to mating was $13.5 \%$ (Fig. 7). In this phase, the male constantly pursued the female trying to cover her. But the female actively fought back with her paws and she did not allow him to mate. On the second day of the estrous cycle (that coincided with the beginning of the estrus stage), there was not any unsuccessful mating. This is probably due to the fact that the male was not tired while the female was willingly and constantly took a receptive posture. On the fifth, sixth and seventh day of the estrous cycle, the frequency of this behaviour was $26.9,23.1,26.9 \%$ respectively.

A successful mating lasted 3-5 seconds. When the progesterone concentration had increased in the female blood (at the end of the estrous cycle) she did not take a receptive posture. As a result, the male ineffectually tried to mate during 2-3 minutes.

At the same stage of the estrous cycle, the female actively avoided mating, only the male showed initiatives to mate. After the first mating, the male lay on the site of mating, waiting for the return of the female. During the estrus phase the initiative to mate came from the female. On the fifth day of the estrous cycle the initiative to mate came from the male again, while the female (actively and passively) began to avoid mating. The male pursued the female, grabbed her by the ears and back of the neck; he bent her to the ground and tried to mate. The female either lay down on her back and fought back with her paws or obediently lay down on the ground without a receptive posture.

During the estrous cycle the male made 233 matings, but not all of them were successful. Presumably 153 successful matings were recorded during the rut. After the «attenuation» of the rut, the male was tired and tried to avoid mating, often climbing upon the wooden constructions, or retreating into the lair. Thus, being fatigued the male crawled into the lair, lay down near the entrance and he did not let the female into the lair, waving her off by his 
paws. In another case: the female, having applied all methods of stimulating the male's sexual activity, lay down in front of the male in a receptive posture. But the male, getting up over her and without trying to cover her, began maliciously wag her ears, the back of the neck and then he went to the lair. During the estrus stage, females often climbed, following the males, upon the tower and into the lair. Then, the females stimulated the sexual activity of the males, achieving of mating.

A high estrogen concentration in the blood during the follicles maturation in combination with low progesterone doses stimulates the LH secretion by the pituitary. Since the Persian leopard belongs to animals with an «instigated» ovulation, the maintaining of a high estrogen concentration in the blood and the ovulation of follicles are stimulated by multiple mating and, consequently, by frequent irritations of the cervix and vagina. Thus, based on the type of female sexual behaviour it is possible (with a permissible error) to judge on the functional activity of the ovaries and the corpora lutea, as well as to determine the beginning and duration of the various stage of the estrous cycle.

Data analysis of the round-the-clock monitoring of animals during the estrous cycle allowed noting the following features of sexual behaviour of the leopard:

- The increasing of the motion and marking activity of the females during the proestrus stage. And, as a consequence, the propagation of pheromones and their influence on the olfactory incentives of the male;

- The activation of the sexual behaviour of the female (flirting with the male, approach to the male from behind and sniffing of his genital area, holding by the tail along the male ridge, «herself substitution») contributed to the maintenance of the male's sexual activity;

- The estrus stage was characterised by the female's adoption of a receptive posture, the lifting of her pelvis and oncoming search movements during the coitus. The latter is necessary for the ejaculation implementation by the male and the transition of initiative to the female;

- During the proestrus stage the female actively avoided mating, during the estrus stage the initiative to mating came only from her;

- During the metaestrus stage the female actively and passively avoided mating, and in this stage the initiative to mate came from the male.

A feature of the male's behaviour is that during the proestrus stage he constantly pursued the female, trying to cover her; and after the first mating in the estrus stage the male lay on the ground and waited for the female to return and for her adoption of a receptive posture. During the sexual saturation and weariness, the male avoided any meeting with the female.

\section{References}

Babichev V.N. 2013. The organization and functioning of the neuroendocrine system. Problems of Endocrinology 59 (1): 62-69. [In Russian]

Etgen A. 2003. Ovarian steroid and growth factor regulation of female reproductive function involves modification of hypothalamus alpha 1-adrenoceptor signaling. Annals of the New York Academy of Sciences 1007: 153-161.

Hussain R., Ek-Etr M., Gaci O. 2011. Progesterone and Nestorone facilitate axon remyelination: a role for progesterone receptors. Endocrinology: 152 (10): 3820-3831.

Kelli B.G., Mermelstein P.G. 2011. Progesterone blocks multiple routes of ion flux. Molecular and Cellular Neuroscience 48 (2): 137-141. doi: 10.1016/j.mcn.2011.07.002

Khusmatullina Z.P. 2009. The amygdaloid complex of brain in the system of the reproductive functions regulation in the organism. Doctoral thesis abstract. Ufa. 54 p. [In Russian]

Lomteva N.A. 2008. Influence of stages in the estrous cycle on the processes of free radical oxidation in female rats under the influence of stress-inducing factors. Problemy reproduktsii 6: 12-15. [In Russian]

Meerson F.Z., Pshennikova M.G. 1988. Adaptation to the stress situations and physical loads. Moscow: Meditsina. 256 p. [In Russian]

Reznikov A.G. 2007. Endocrinological aspects of the stress. In: International Journal of Endocrinology 4: 11-17. [In Russian]

Rozen V.B. 1984. Basics of Endocrinology. Moscow: Vyisshaya shkola. 336 p. [In Russian]

Rozhnov V.V., Lukarevskiy V.S. 2006. The programm of the recovery (reintroduction) of the Persian leopard in the Caucasus. A.N. Severtsov Institute of Ecology and Evolution. Moscow: KMK Scientific Press Ltd. 65 p. [In Russian]

Rozhnov V.V., Lukarevskiy V.S., Sorokin P.P. 2007. The reintroduction of leopard (Panthera pardus L., 1758) in the Caucasus: molecular-genetic aspect. In: V.V. Rozhnov, F.A. Tembotova (eds.): Mammals of the mountain areas. Moscow: KMK Scientific Press Ltd. P. 275-278. [In Russian]

Tang Y., Janssen W., Hao J., Roberts J.A., McKay H., Lasley B., Allen P.B., Greengard P., Rapp P.R., Kordower J.H., Hof P.R., Morrison J.H. 2004. Estrogen replacement increases spinophilin - immunoreactive spine number in the prefrontal cortex of female rhesus monkeys. Cerebral Cortex 14 (2): 215-223.

Tetel M. 2009. Nuclear receptor coactivators: essential players for steroid hormone action in the brain and in behavior Journal of Neuroendocrinology 21 (4): 229-237.

Toran-Allerand C. 2005. Estrogen and the brain: beyond ERalpha, ER-beta, and 17 beta-estradiol. Annals of the New York Academy of Sciences 1052: 136-144.

Ukhtomskiy A.A. 1966. The dominant. Moscow; Leningrad: Nauka. 273 p. [In Russian]

Vunder P.A. 1973. Gender endocrinology and reproduction. Moscow: Meditsina. 216 p. [In Russian] 


\title{
ОСОБЕННОСТИ ПОВЕДЕНИЯ ПЕРЕДНЕАЗИАТСКОГО ЛЕОПАРДА (PANTHERA PARDUS SAXICOLOR) В РАЗЛИЧНЫЕ ФАЗЫ ЭСТРАЛЬНОГО ЦИКЛА
}

\author{
М. М. Эртуев, У. А. Семенов \\ Сочинский национальный парк, Россия \\ e-mail:mr.ertuev38@gmail.com,umar-semenov@rambler.ru
}

\begin{abstract}
Реализация программы реинтродукции леопарда на Кавказе в России позволила осуществлять детализированный видео мониторинг различных аспектов жизни подвида в вольерных условиях специального построенного «Центра восстановления леопарда на Кавказе». Важнейшим этапом программы стало формирование пар и получение потомства от особей, отловленных во взрослом состоянии в естественной среде и помещенных замкнутые контуры вольер. Сложное половое поведение леопардов, имеющее различные фазы эстрального цикла, идентифицируется проявлением характерных признаков на разных этапах. Усиление двигательной и маркировочной активности в период проэструса. Заигрывание, способствующие поддержанию половой активности самца и принятие самкой рецептивной позы в период эструса. Избегание спаривания самкой в фазе проэструса. Переход инициативы спаривания к самцу и пассивное поведение самки на этапе метаэструса. Большое количество садок обусловлено биологией вида, леопард относится к животным со «спровоцированной» овуляцией, поэтому многократные спаривания стимулируют поддержание в крови высокой концентрации эстрогенов и способствуют овуляции фолликулов. В результате сделаны выводы, что по форме полового поведения самок можно с допустимой погрешностью судить о функциональной активности яичников и желтых тел, а также определить начало и продолжительность различных фаз эстрального цикла.
\end{abstract}

Ключевые слова: переднеазиатский леопард, половое поведение, садка, спаривание, эструс. 